\title{
African Indigenous Knowledge System and Environmental Sustainability
}

\author{
Alokwu Cyprian Obiora ${ }^{1}$, Ezenwaji Emma Emeka ${ }^{2}$ \\ ${ }^{1}$ Department of Religion and Philosophy, Paul University, Awka, Nigeria \\ ${ }^{2}$ Department of Geography and Meteorology, Nnamdi Azikiwe University, Awka, Nigeria
}

Email address:

obicko1@gmail.com (A. C. Obiora),emmaezenwaji@gmail.com (E. E. Emeka)

\section{To cite this article:}

Alokwu Cyprian Obiora, Ezenwaji Emma Emeka. African Indigenous Knowledge System and Environmental Sustainability. International Journal of Environmental Protection and Policy. Vol. 3, No. 4, 2015, pp. 88-96. doi: 10.11648/j.ijepp.20150304.12

\begin{abstract}
Observers in international political arena have brought to public knowledge the fact that environmentalism has gradually crept into international politics. This is because of the commonalities between environment and political economy. Governments at various levels, environmental policy makers, have therefore sought solutions from scientific, economic and political dimensions to address the problems while neglecting the important role indigenous knowledge system could play in this much needed synergy. After careful research of some related literatures, the paper emerged with the findings that noninclusion of African indigenous knowledge in environmental discourse over the years was simply based on the assumption that scientific investigation and findings was the only authentic method and acceptable means of providing information/solution to myriad of problems of the environmental sustainability. It, therefore, strongly argues that solution to these problems particularly in Africa requires a multi and interdisciplinary approach and not just scientific inquiry. It calls attention to the fact that African indigenous knowledge system (which still remains untapped resource) could beuseful, in fostering the much needed culture of ecological responsibility. To achieve this, it recommends a new paradigm to environmental discourse where natural science integrates with African indigenous knowledge to achieve environmental sustainability.
\end{abstract}

Keywords: International, Politics, African, Indigenous, Ecological

\section{Introduction}

There is no doubt that what is on the lips of environmentally concerned people, including the international community and Nigeria in particular, is the issue of safeguarding our gradual but increasingly dilapidating environment. It has been mentioned earlier that confronting the environmental challenges of our time requires an interdisciplinary and even multi-dimensional approach. One of such approaches is the use of African indigenous knowledge system.

For us to understand the importance of African indigenous or traditional knowledge system in contributing to ecological sustainability, we need to have an understanding of the African world views, its cultural heritage, values and ecological construct. We also need to understand African myths that explain the various cultural practices of the African people. Understanding the traditional ecological knowledge of the Africans is important for the consideration of a broad range of questions regarding their nature-human relations. This is because different groups of people in various parts of the world perceive and interact with nature differently, and have different traditions underpinning their ecological ethics. Their perceptions and knowledge of the universe are in part shaped by their values, worldviews, and religion in the broader sense. In other words, when people attempt to answer fundamental questions about the place and relationship of humanity with the universe, their ideas about the universe accumulate and definite views and systems begin to emerge (Ibe, 2003). As a thought process, there can be no end to the development of people's views about the universe. This world view can be defined as "the complex of their beliefs and attitudes concerning the origin, structure of the universe and the interaction of its beings with particular reference to man (sic)" (Metu, 1999). World views are embedded in the people's experience and, then, expressed or re-enacted in their cultures (Kalu, 2000). Nature is full of mystery and such mystery poses a challenge to people's understanding of the society in which they live. Society, therefore, constructs a world view in an attempt to unravel the mystery of the universe. The society's world view 
underpins their culture. The society constructs culture in their encounter with and effort to understand and relate with nature, in order to harness its resources for the nurture of the society.

From the above, it is clear that environmental discourse is heavily loaded with statements about the way indigenous and traditional societies relate to their environment (Cooper and Palmer, 1998). For example, the report of the World Commission on Environment and Development (the Brundtl and Report), referred to the harmony with nature and the environmental awareness which characterized the traditional way of life of many indigenous people (World Commission on Environment and Development, 1987). Similarly, Margaret Thatcher, the former British Prime Minister, praised the primitive people of the rain forest for having a "one-ness" with their environment that has been lost in the urban jungle (Cooper and Palmer, 1998). Furthermore, in his opening address to the United Nations Conference on Environment and Development in 1992, (the Rio Earth Summit), Maurice Strong advised as follows: "we must reinstate in our lives the ethic of love and respect for the earth which the traditional peoples have retained as central to their value system" (United Nations, 1993). The most important distinction to be drawn from the above assertions, is between beliefs about the way indigenous and traditional peoples act towards their environment (that they do not dominate or destroy it, that they live sustainably within it), and beliefs about what they think, feel or know about their environment-that they respect it and possess ecological wisdom (Cooper and Palmer, 1998).

The above description of indigenous people and their relationship with their environment is evidently true about indigenous peoples of Africa. Before the coming of Christianity and the introduction of Western world views, African peoples lived and understood their existence in terms of the belief system and cultural constructs of the society to which each belonged. In Africa, there are different ideas and world views about the world just like in other parts of the world. These views are expressed in myths, legends, proverbs, rituals, symbols, beliefs and wise sayings (Metu, 1985). Although each ethnic community has its own beliefs about humanity and the world around it, anthropological and ethnological studies have made it possible to observe some general characteristic features of African world view (Mugambi, 1988). The generalisation of these characteristic features has in no small way helped us to have a common understanding of the African world view since the task of describing a world view shared by all Africans or even a large section of African societies would almost be an impossible task in this work. We can only attempt to encapsulate some of these general characteristic features.

\section{Concepts of Traditional Ecological Knowledge (TEK)}

Scholars are not in agreement over the use of the term "traditional". Some consider it derogatory, backwardness, and instead favour "indigenous" or "local." Others point out that many indigenous peoples themselves see "tradition" in a positive light. They do not take it to mean inflexible adherence to the past but rather to mean time-tested and wise (Warren, 1992: 1). This paper uses both traditional and indigenous interchangeably in a non-derogatory sense.

In the search for an environmental ethics towards an ecologically sustainable society, indigenous peoples and traditional ecological knowledge have attracted considerable attention from both scholars and environmental movements as a viable option to be considered. Traditional ecological knowledge may be defined as "a cumulative body of knowledge, practice and belief evolving by adaptive processes and handed down through generations by cultural transmission, about the relationship of living beings (including humans) with one another and with their environment" (Possy and Dutfield, 1996). As a body of knowledge system, traditional ecological knowledge includes the worldview or religious traditions of a society. It is both cumulative and dynamic, building on experience and adapting to change, as societies constantly redefine what is considered "traditional." (Grenier, 1998). It is an attribute of societies with historical continuity in making a living in a particular place. African Traditional ecological knowledge may therefore be considered as a sub-set of African indigenous knowledge, defined as local knowledge held by African peoples or local knowledge unique to an African cultural society (Berkes, 1999).

African traditional ecological knowledge is comprised of a wide range of understandings of ecosystems and this includes traditional modes of agriculture especially in the form of shifting cultivation. Essentially, in this agricultural system, a family clears or slashes and bums a piece of wooded area. The ashes act as fertilizer for the next two years or so. Different types of crops are grown concurrently on the same plot as a simulation of biodiversity of a natural rainforest ecosystem. This protects the soil from turning into laterite, bricklikesoils. After three years of cultivation, one moves on to another piece of land while the former stays fallow to regenerate. Regeneration may take up to ten years or more. However, such asystem entails a reasonably low population density. The system of shifting cultivation was practiced in most African countries until recently when it became no longer possible due to high population densities (Kapileni, 1994). Other areas where traditional environmental knowledge is projected includes agro forestry, animal raising, hunting, fishing and gathering (Wolfgram, 2006).

\section{Methodology}

The research method adopted is qualitative which according to Merriam (1998) is an approach which recognises that meaning emerges through interaction and is not standardized from person to person as in quantitative research and thus allowing the researcher to study issues in detail without predetermined categorised analysis. This method was used because it assures an internal data collection which is achieved through generation of funs that 
encourages the subjects to participate in the research. The sampling method adopted was purposive sampling. We employed this method because we had to select respondents based on some defining characteristics that makes them holders of specific data needed for the study (Maree, 2007).

\section{Result}

Traditional environmental knowledge is not stored in books; rather it is retained and transmitted verbally, through subsistence practices and through cultural myths and taboos.

It is interesting to observe that the significance of traditional ecological knowledge-(TEK) has been recognized in the international arena and that the number of publications on this subject has grown rapidly since the 1980s (Werner, and Begishe, 1980). However, its relevance in environmental management and development discourse in general, including the relationship between it and Western science has remained controversial (Wolfgram. 2006). This controversy emanates from the fact that scientists tend to be sceptical, demanding evidence when confronted with traditional knowledge that may not easily lend itself to scientific verification (Wolfgram, 2006). The problem of credibility is compounded because some traditional knowledge which may include elements, such as the religious dimensions of the environment, (these could not be easily verified in a scientific manner), do not make sense to science. For example, many of the African societies believe that some non-living parts of the environment (including rivers and mountains), as well as all living beings, have spirit or at least is connected to one spirit or the other. Asante vividly captures this point when he observed that:

Their (i.e.) African's cosmologies were based on the existence of a Supreme Being who was spirit and creator, and the source of all power and energy. He granted existence to all created things. He animated the gods, the spirits and human beings, animals, rivers, trees, rocks and all matter. Their metaphysics conceived the creator as the Universal Vital Force that animated and energized all things whose real essence consisted not in matter but in the energy and power infused into them by the Creator (Asante, 1985).

In the face of such a belief grounded purely on religious conviction, it becomes difficult for science to make any scientific verification because it has no tools for the study of the spiritual dimensions of the environment. Nevertheless such beliefs are important for our understanding of traditional ecological knowledge.

On their own part, traditional knowledge holders are also sceptical of scientists, and tend to dismiss scientists who do not have extensive first-hand knowledge of a specific land area. As a result, they are often baffled by the preoccupation of scientists to measure and quantify almost everything and dismiss any that does not hold valid scientific proof.

Power relations concerning authority over knowledge therefore becomes a big issue here. This tension becomes more complex because not many "educated people" are willing to accept the fact that Western scientific methodology is merely one way, and not the only way, to acquire knowledge and provide solutions to humanity's multifarious problems. Unfortunately, the superiority of scientific method has gained more acceptance as the dominant knowledge system at the negligence of traditional knowledge. As a result of this perceived "superiority" of Western science over traditional knowledge, Western science is seen as having a monopoly on truth and regards knowledge and insights that originate outside institutionalized Western science as unacceptable fallacy. Practitioners in the field of Western science, therefore tend to dismiss understandings that do not fit their own which come from other bodies of knowledge such as TEK. As a result, it has become the sole basis of environmental decision-making by many environmental policy makers and development agencies throughout the world including Africa.

However, in his defence of TEK, Hunn articulates the following reasons and insists that traditional environmental knowledge should be considered as another method of acquiring knowledge alongside Western method and therefore argues that it should be preserved because:

- It is a locally grounded science that supplements Western science.

- It is an intellectual monument to our common humanity.

- It provides a kind of human alternative or human diversity option to the globalization of the Western market culture.

- The use of TEK contributes to conceptual pluralism, and expands the range of approaches and information needed to solve environmental problems (Hunn, 1999).

Furthermore, Wolfman sees the potential of TEK to build upon ecologically sustainable local knowledge and belief systems as an important asset for environmental conservation. This potential for him, justifies its significance (Wolfgram, 2006) . He argues that there are tangible and practical reasons why TEK is important for the rest of the world's people by outlining the following points:

It is a source of biological knowledge and ecological insights.

It is important for the sustainability of difficult-to-manage ecosystems such as tropical forests.

It is important for community-based conservation by connecting human values with conservation values.

In-depth local environmental knowledge and trends over time for a given site are important for environmental assessment.

Traditional knowledge is essential for development, especially for "bottom-up" (as opposed to top-down) development planning with people.

Traditional ecological wisdom is a source of inspiration for environmental ethics. Belief systems of many indigenous groups incorporate the idea that humans are part of the natural environment, and their relationship with nature may be characterized as peaceful coexistence.

Based on the inestimable importance of TEK, Posey and Graham caution that Traditional knowledge and Western science need not be thought of as opposites, rather, it may be 
useful to emphasize the potential complementarities of the two, and to look for points of agreement rather than disagreement (Darrell and Balee1989: 76). These observations are significantly instructive. This significance reflects the explosion of interest in TEK in recent years and therefore justifies the need to derive ecological insights from indigenous practice, and the need to develop a new ecological ethic based in part on indigenous wisdom.

Our understanding of the need to appreciate African traditional knowledge and the important role it could play in the search for a synergistic approach to the current global ecological crisis when it is integrated with other ethics that relate to ecological sustainability is necessary.

\section{Discussion}

How we think about the world affects the way we live in and relate with it. This is very important for our discussion because our understanding of nature-our cosmology, affects the way we understand ourselves, the way we relate to other people, and, of course, the way we relate to the earth and other forms of life (Sindima, 1990). From her past colonial experience, the people of Africa have been influenced by a cosmology inherited from the West. This is the whole point made in "Things Fall Apart" by Chinua Achebe and other "pan Africanists" about the British colonial exploitation of Africa. This Western cosmology is mechanistic in nature. It is a perspective that views all things as lifeless, commodities to be understood scientifically and to be used for human ends. This is contrary to the African understanding of the cosmos.

The African conceives of the universe beyond the diversity of its forms as a fundamentally one cosmic reality in its visible and invisible forms. To some extent, both the visible and the invisible elements of nature are interlinked, human life is inseparably bound to nature, and both human life and the life of other creatures are one with the divine. It is therefore unthinkable for Africans to objectify nature as the other' or to see nature as having only instrumental value. The African notion of bondedness of all things fosters a sense of care for all of creation. This sense of bondedness is embedded in individual personality and this guides the individual's behaviour from birth to death, through puberty and marriage. The processes of acquiring the sense ofbondedness, involve some levels of socialization through which the individual as it were is implanted with the sense of bondedness. This therefore explains why when African people die outside their ancestral home, they would be brought back to their place of birth to be laid to rest so as to be gathered with the rest of their kindred (Pobee, 1979). Africans do not allow their own to be buried outside their birth place.

According to Ikenga-Metu, "the dichotomy which is so characteristic of the West, especially the Greco-Christian world view is strikingly absent in African world view. There is no clear cut distinction or opposition between the visible and the invisible, the material and the spiritual, the temporal and the non-temporal, the sacred and the profane" (Metu.
1985). This is against the Western cosmology which is static, objective, dichotomised and in fact dualistic in its distinction between body and soul, matter and spirit (Hord, 1995). The African is, of course, sensitive to his or her external world, to the material aspect of beings and things. For him or her, matter in the sense of the European understanding is quite different. Matter in the African understanding serves only as a system of signs which translates the single reality of the universe (Metu, 1985). In this sense, the whole universe appears as an infinitely small and at the same time an infinitely large, network of life forces which emanate from God and end in God who is the source of all life forces. It is he who vitalizes and devitalizes all other beings, all the other life forces (Hord,199). Ibe, quoting Egbujie succinctly summarises this African understanding of cosmic oneness thus: "Beyond and above the visible tactile physical world, there is a non-visible, non-tactile world which envelops the former. It permeates the former through and through; it is simultaneously within an outside of the earth and the seas" (Ibe, 2003). Consequently, there is not only "less separation between subject and object, between self and non-self, but fundamentally all things share the same nature and the same interaction one upon another ... the living, the dead and the first ancestors, from the stone to the divinities a hierarchy of power but not of being, for all are one, all are here, all are now" (Metu, 1985). As a result of this cosmic oneness, it is generally believed that the deities inhabit the natural phenomena with which they are associated like rivers, forests, sky or sun. The ancestors are believed to be around their homes and hearths and take part in all important family affairs. This idea of cosmic oneness or corporate identity, as Mugambi calls it, is central in African cosmological thinking. According to him, thecommunity to which a person belongs extends to include past and future generations. The family extends beyond the conjugal unit to include the whole ethnic clan, and more extensively, the whole ethnic group (Mugambi, 1988).

In terms of creation story, there abound almost irreconcilable versions of creation stories in Africa. These differences could be as a result of different patterns of observation used by different societies to explain their existential reality. While some societies use models drawn from the visible physical world (the order of the planetary bodies), others draw their models from ecology-the sea, desert or fauna. Despite these differences in creation stories, the African understanding of creation is unanimously religious in nature. According to Mbiti, when people in Africa say that the universe was created by God, they are automatically looking at the universe religiously (Mbiti, 1980). Based on Mbiti's observation, we can say, therefore, that the African view of the universe is profoundly religious as opposed to the Western mechanistic view. Africans see the universe as a religious entity and treat it as such (Ibe, 2003). The African traditional cosmology views their existence as their religion and their tradition as their existence. The two cannot be separated. "They eat religiously, drink religiously and for them religious activities invigorate the person, 
supplying him (sic) with help from deities and unseen external forces and also protecting the person from dangerous activities of the spirits" (Madu, 1996).

The African understanding of the universe is two-fold: the visible world and the invisible world. While the visible world is populated by men (sic) and all material surroundings like sky, mountains, earth, rivers, forests and so on, the invisible world consists of the heavenly part (sky) inhabited by the creator and deities, and "the spirit land" of the ancestors, the spirits, disembodied spirits, all located somewhere in the ground (Ibe, 2003). Following this classification, many African people hold that the universe is in the form of a three-tier creation, namely: the heavens, the earth and the underworld, which lies below it.

The heavenly part of the universe is the home of the stars, sun, moon, meteorites, sky, the windand the rain, with all the phenomena connected with them such as thunder and lightning, storms, eclipses and so forth. It is also thought to be the home of God, although people cannot locate where he dwells. The sky', heaven', or beyond the clouds' are used to describe his dwelling place. While some people believe that God has other beings living with or close to him-his messengers or ministers, others thought he is completely living alone. The earth, too, is full of created things. It is symbolically looked upon as the mother of the universe hence the expression- "mother earth or the goddess earth" (Metu, 1985).

From the foregoing, it is evident enough that the significance of the African world view in relation to ecological consideration is sine qua non to understanding African indigenous ecological ethics in order to be able to offer the synergistic solution to the current ecological problems in Africa. This is because the African world view is responsible to a very large extent for the profound communion Africans have with the universe. Ikenga-Metu agrees with this assertion when he argues that:

The main object of an African is to live a life in harmony with humanity and with nature. Man strives to be in harmony with God, the deities, and his fellow men (sic) both living and dead. He feels himself in intimate rapport and tries to maintain harmonious relationship with the animal, vegetation and other elements and phenomena in the universe. For him, the first evil is disintegration for this would spell disaster for himself and his immediate world. The ideal thing is integration, communion and harmony (Metu, 1985).

The above quotation about the African people's sense of intimacy and harmonious relationship with nature justifies the belief that Africans are ecologically responsible even before the advent of Christianity. This is evidently seen in the African belief that the deities have the responsibility to police people as it were, to ensure integration and harmony of the ontological order. This consciousness compels people to always ensure that their relationship with nature is not in any way impaired. Any impaired relationship with nature, they believed, would attract unfavourable consequences to them.

The consciousness mentioned above shows that the importance of moral order in African societyis of fundamental significance. It is understood that God gave moral order to people so that they might live happily and in harmony with one another and with nature. This moral order is instrumental to the establishment of customs and various institutions in all societies, to safeguard the life of individuals and the community of creatures which humans are part of. Each society is able to formulate its values because of this moral order. These values deal with relationship among people, and between people and God and other spiritual beings, and humanity's relationship with the world of nature (Ibe, 2003). To act contrary to this moral order is considered an abomination against nature and humanity. The functionality of moral order ensured that Africans maintained and lived in close relationship and harmony with nature before the introduction of the Western culture and Christian faith which dichotomizes and distinguishes between spirit and matter on one hand and between man and nature on the other hand.

\section{Africa's Past Ecological Experience}

Before the penetration of Africa by the Europeans, Africans had developed a unique system of preserving their environment (Kalipeni, 1994). This is in spite of the fact that traditionally, Africans had no written literature regarding their relationship with nature. However, this does not imply that they were environmentally bankrupt. On the contrary, they expressed their beliefs and attitudes to environment through myths, stories, proverbs, songs, taboos and ritualsoral history. Samson Gitau in his book, The Environmental Crisis, argues that Africa has a rich environmental culture and that if one wishes to understand the traditional African attitudes towards environment, he or she has to listen to their myths, taboos, stories, proverbs, and beliefs. One will also have to observe their symbols and rituals (Gitau, 2000). For example, among the Igbos of Nigeria, some ethical prescriptions-taboos-are associated with some rivers and forests to safe guard them from pollution, abuse and exploitation. In other African societies, certain animals and plants are associated with spirits in a particularly close way that ensured environmental sustainability (Forde, 1998).

In this manner, African culture had been able to successfully control the proper use of the earth over the years until the culture of the industrial market became a global process-attempting whether by seduction or coercion to destroy all other existing cultural forms (Alokwu, 2009). In doing so, it has created its own contradictions, giving humanity the power to extinguish not only itself but also many of the world's species. We would like to argue strongly on the basis of the above assertion, that the loss of African way of life, and with it, of cultural identity, lies at the root of our environmental problems, socio-economic and political underdevelopment. Before the advent of Western Missionaries and industrial market culture, Africans were noted for their rich cultural heritage. This had enormous influence on their life.

In those good old days when moral order was strictly 
observed in traditional Igbo society, children were taught to observe some ecological ethics. They were taught not to defecate near the village stream where drinking water was fetched. They were taught that violation of this prohibitionthe moral order, would attract some severe sanctions from the deity who owns the stream. Children were taught to observe the moral code which the Igbos called omenani. This omenani was believed to have been handed down from the earth goddess from time immemorial. The elements of omenani are made up of purely, religious, social, economic and political restrictions (Allen, 1951). These prohibitions known as nso ani (what the earth-goddess abhors) are meant to enforce moral order in the society and people strictly adhered to them. Ilogu articulates some of the components of nso ani which could attract severe penalties from both the society and the gods to include but not limited to the following;

- Stealing yam either from the barn or from farm

- Homicide

- Incest

- Suicide by hanging

- Poisoning someone

- Theft of domestic fowls especially a hen in its hatching pot

- Killing of a pregnant goat (Ilogu, 1974).

A careful look at the above list of what is considered as "nso ani" shows that most of the prohibitions (which if violated could attract severe punishments) have some ecological implications which are meant to safeguard nature as a whole. Generally speaking, traditional ecological ethics was based on the maxim; "do not do to others what you would not want them to do to you". This maxim, however, is not peculiar to Africans. Indigenous peoples all over theworld-Pacific Islanders, American Indians, and Aboriginal Australians-have similar mechanisms informed by their beliefs and philosophies regarding the land and their relationships to the land and the rest of the environment (Sowunmi, 1995). For example, it is widely believed among Africans that the land is "mother"-the source of nourishment, survival and indeed life. It shouldbe reverenced. In some communities, it is believed that land cannot be owned by the people since the understanding is that the people are owned by it. A typical example of this is the case of the Anam people of Anambra West of Anambra state-Nigeria. The traditional land ownership is communal in nature. No single individual owns a land. The entire community owns the land in trust for the earth goddess.

It has been observed that indigenous people have an excellent knowledge of their environment. This afforded them the wisdom of not attempting to over exploit its wide range of resources. Many communities are known to use more than a hundred different plant species for dietary, medicinal and other domestic purposes. The indication of their harmonious existence with the environment, and judicious exploitation of it, is that they can remain for generations, over thousands of years, in the same area; hunting was solely for food and other basic needs, not for sport or fun. Communal spirit and kinship bond were very strong, negative individualism, selfishness and greed were discouraged.

Traditional ecological knowledge promoted harmony between humankind and the environment and a healthy concept of how to relate to it. Hitherto what has been known about African cultures has come largely from academic studies in ethno-archaeology and anthropology, usually by foreign scholars who often regarded the people as "primitive". Colonizing powers imposed on these people their own cultures, which they in their arrogance and ignorance considered to be superior and "civilized" (Wolfgram, 2006). The fact that the so-called superior cultures have been the ones largely responsible for the degradation of the environment as well as the economic crisis of the impoverished ex-colonies is a clear indication of the failure of their ideologies and life styles (Sowunmi, 1995).

A reinvention of past African ecological ethics and the sets of moral orders referred to earlier in African society would be necessary in the face of the current ecological crisis bedevilling the entire universe. This is because the implication of the current global earth crisis is the destruction and distortion of our hitherto beautiful environment in many ways. The extent of this distortion is such that human existence on the surface of the earth is endangered. The threat to human existence and bio depletion' reminds us of Fidon Mwombeki's caution that "humanity is dangerously capable of destroying itself and the creation" (Mwombeki, 2001). The current rate of the earth crisis emanating from the quest for development and other human activities also increases the fear expressed by McDough that "when the earth is disfigured and its fruitfulness impaired, then every succeeding generation of people is automatically condemned to poverty" and the possible extinction of the whole universe (McDough, Sean. 1990). The consequences of focusing only on immediate ends and not thinking intergenerational occasioned by the Western mechanistic view of the world are a contributory factor to the environmental degradation and other problems of our time. This calls for a behavioural or attitudinal change in order to avert the impending doom described above. This change could come from TEK which emphasizes the essence of being human-"my humanity is caught up and inextricably bound up in yours ... I am because I belong. This fosters a strong sense of community. The African concept of community recognizes that we live in one household, that we need one another to survive and thrive. The word "community" refers to more than a mere association of atomic individuals. The term suggests bondedness; it refers to the act of sharing and living in communion and communication with each other and with nature. To communicate is to stay in a relationship and inculcate a sense of sharing. This is what Sindima meant by saying that "in community we share and commune with selves who are other than ourselves and yet united to us." Sindima goes further to suggest that in Africa "persons are not individual entities or strangers to one another". It is the community which "defines the person as person, not some 
isolated static quality of rationality, will or memory" (Shutte, 1993). They are nature itself seeking fullness in the actuality of present life. Since people belong to the fabric of life, their life-like nature-must be respected. This call for respect of persons is also a charge to the community to create possibilities for persons to realize full personhood in a community of life where all are bonded together, everyone is responsible for everyone else".

Setiloan's biocentric ethics sheds more light in our understanding of community in relation to African context. He uses the term biocentric ethics to emphasize the inclusive nature of community life in all its forms (Setiloane, 1995). The term "biocentric" was originally formulated by Leopold in his notion of land ethic which implies an expansive notion of community. This term was later broadened as "ecocentric" or "biocentric" ethics by different philosophers over the decades to mean that we are all part of a biotic community (Cock, 2007). In a community there is the structure as well as mutuality of care, assurance of belonging, sustenance and support. The African notion of "earth community" refers to relations of interrelatedness and interdependence, without rivalry and oppression. It is about community and reconciliation, wholeness, connectedness, love, sacrifice, generosity, and welcoming the It maintains that all living things have intrinsic worth-value in and of themselves-not just instrumental or utilitarian value. He concludes that land ethic involves the extension of our human ethics to include the other species with which we share the land. In this perspective, all ethics ... rests upon a single premise: that the individual is a member of a community with interdependent parts and the land ethic simply enlarges the boundaries of thecommunity to include soil, waters, plants and animals). Therefore, "biodiversityis necessary not only for utilitarian and humanitarian reasons (for maintaining the present and future health of the entire biosphere, for enhancing the quality of life, and for aesthetic enjoyment), but its own sake. Ecocentrism expands the goods of the human community to embrace and include within it the good of the biotic community" (Merchant, Caroline. 2004).

Setiloane's ecological ethics is also expressed in the African principle of live and let live. In recognition of this principle, the Igbos of Nigeria strongly believes in their notion of "Egbe belu, ugo belu. Nke si ibe ya ebena, nku kwa $y a$ ". When loosely translated, it reads; let the kite perch as well as the eagle. If anyone refuses the other, let its wing be cut off. The rationalization of egbe belu principle tries to enforce respect for all life forms. It is a concept which recognizes the right of existence of all life and insists that none has the right of refusal to existence to other life forms. The egbe belu principle guarantees protection to all the community members including the weaker ones who would not have been able to protect themselves. Alokwu (2009) observesthat the application of this principle ensures safety in the whole community of life as none is marginalized for any reason. This healthy relationship which the egbe belu principle promotes eliminates greed in its various dimensions as only one's legitimate needs are sufficiently satisfied.
Therefore, it is sinful for one not to recognize the right of existence of others or to disturb the constant cycle of existence which affects the corporate existence of the community. In order to maintain this egbe belu principle, the Igbos (and most African societies) developed the idea of taboos and totemism where certain groups of species-animals, plants, rivers etc. are prohibited from being killed or destroyed. It is generally believed that non adherence to this prohibitive order would attract the wrath of the gods on humanity. In a home there is the structure as well as mutuality of care, assurance of belonging, sustenance and support.

\section{Conclusion/Recommendation}

From the discourses so far, the paper has succinctly dealt on the need for the inclusion of TEK as environmental model for entrenching environmental responsibility and sustainability in Africa. In the search for collaborative solution to the current environmental crisis the paper suggests that African scientists and teachers should evolve a new approach to the study of natural sciences that integrates indigenous principles of natural resource conservation and management through TEK to ensure a holistic approach to the study of natural organisms and systems.

It further recommends that African countries should mount deliberate programmes of training to produce top level experts in the various fields of natural resources and the environment who are also interested in African tradition. The objective should be to create a pyramidal structure of expertise, with those in the top echelon constituting the critical mass of training for innovation in environmental sustainability.

African governments and wealthy individuals should be encouraged to assist researchers to conduct competitive and innovative research in African environmentalism. Locally designed educational programmes on the value of natural resources management should be integrated into educational curricula at all levels.

\section{References}

[1] Andrew, F. Walls. (1976). "Towards Understanding Africa's Place in Christian History" in John Pobee. Religion in Pluralistic Society. New York; E. J. Brill.

[2] Asanie, E.(1985). "Ecology: Untapped Resources of PanVitalism. in Africa" African Ecclesial Review 27.

[3] Berkes, F.(1999). Sacred Ecology: Traditional Ecological Knowledge and Resource Management.

[4] Bums, A. (1951). History of Nigeria. London: George Allen and Unwin Ltd.

[5] Cooper, F. and Palmer, J. A. (1998). Spirit of the Environment. Religion, Value and the Environmental Concern. London: Routledge. 
[6] Darby, K. R. (2006). Ecology, Economy and God, Theology that Matters. Minneapolis: Fortress Press.

[7] Dary II Forde (ed) (1998). African World. Studies in the Cosmological Ideas and Social Values of African Peoples. Hamberg: LIT James Currey with the IAI.

[8] Emeife, I. M. (1999). God and man in African Religion. A Case Study of the Igbo of Nigeria. Enugu: Snaap Press Ltd.

[9] Emeife, I. M. (1985). Comparative Studies of African Traditional Religions. Onitsha: Imico Publishers.

[10] Ezekiel, K. (ed) (1994). Population Growth and Environmental Degradation in Southern Africa. United States of America: Lynne Reinner Publisher.

[11] Fred, L. H. (Mzee Lasana Okpara) and Jonathan, S. L. (1995).(eds) "I am Because We Are".

[12] Grenier, L. (1998). Working with Indigenous Knowledge. A Guide for Researchers. Ottawa: International Development Research Centre.

[13] Gwinyia H. M. (1995). The origins of Development of the African Theology. Maryknoll: Orbis Books

[14] Hunn, E. (1999). The Value of Subsistence for the Future of the World. Ethnoecology, Situated Knowledge/Located Lives. Tucson: University of Arizona Press.

[15] Ibe, M. J. (2003). Environmental Ethics and Politics in Developing Countries.

[16] Ilesanmi, S. (1997). Religious Pluralism and the Nigerian State. Athens: Centre for International Studies, Ohio University.

[17] Ilogu, E.C. (1974). Christianity and Igbo Culture. Onitsha: University Publishing Company.

[18] Jacklyn, C. (2007). The War against Ourselves. Nature, Power and Justice. Johannesburg: Wits University Press.

[19] Jenkins, P. (2002). The Next Christendom. New York; Oxford University Press.

[20] JNK, M.(1988). African Heritage and Contemporary Christianity. Nairobi-Kenya: Longhorn Publishers.

[21] John, S. P. (1979). Toward an African Theology. United States of America. Parthenon Press.

[22] Kalu, O. U. (2000). Power, Poverty and Prayer. The Challenges of poverty and pluralism in

[23] African Christianity, 1960 - 1996. New York: Peter lang.

[24] Leal, R. (2004). The Environment and Christian Faith. Australia: St. Paul's Publications.

[25] Louw, J. P. and Eugene A. N. (eds) (1989). Greek-English Lexicon of the New Testament based on semantic domains. Vol. 1. Cape Town: Bible Society of South Africa.

[26] Madu, R. O. (1996). African Symbols, Proverbs and Myths: The hermeneutics of Destiny. Frankfurt am main. Peter lang.

[27] Mbiti, J. (1980). African Religion and Philosophy. Ibadan: Heinemann

[28] McDough, S. (1990). The Greening of the Church. New York: Orbis.
[29] Menkiti, I. A. (1979). 'Person and Community in African Traditional Thought”. In Wright, R.A.(ed) African Philosophy. New York: University Press of America.

[30] Merchant, C. (2004). Reinventing Eden: The Fate of Nature in Western Culture. New York: Routledge.

[31] Mwombeki, F.R. "Ecology in the New Testament"

[32] Okadigbo,C. (1975). The Philosophical Foundations of the African Personality. Unpublished Notes. Enugu: Bigard memorial Seminary.

[33] Patrick, H.(2006).Unsustainable. A primer for Global Environmental and Social Justice (New York: Zed Books)

[34] Posey, D. A. and Graham, D. (1996). Beyond Intellectual Property: Towards Traditional Resource Rights for Indigenous Peoples and Local Communities. Ottawa: International Development Research Centre

[35] Posey, D. A. and William I. B.(1989).(eds). Resource Management in Amazonia: Indigenous and Folk Strategies. New York: New York Botanical Gardens.

[36] Samson, G.(2000).The Environmental Crisis. A Challenge to African Christianity (Nairobi: Action Publications)

[37] Setiloane, G. (1995). "Towards a Biocentric Theology and Ethic Via Africa". Journal of Black Theology in South Africa 9: (1) May.

[38] Shutte, A. (1993). Philosophy for Africa. South Africa: University of Cape Town. p 46

[39] Simone, A.M. (1999). Thinking About African Urban Management in an Era of Globalization. African Sociological Review: 3(2), 69-98,

[40] Sindima, H. (1990).“Community of Life: Ecological Theology in African Perspective" in B.C. Birch, W. Eakin and J.B. McDaniel, Liberating Life: Contemporary Approaches to Ecological Theology. Maryknoll: Orbis

[41] Sowunmi, A.A. (1995).Giver of Life -"Sustain Your Creation" in Hailman, David, G. (ed) Ecotheology.Voices from South and North. New York:Maryknoll.

[42] Steven A. W.(2006).Global Development and Remote African Villages. Environmental Conservation and Cultural Survival in Cameroon. United States of America: The Edwin Mellen Press.

[43] Story Earth (1993). Nature Voices on the Environment. A Compilation of Inter Press Service (California: Mercury House,)

[44] United Nations(1993). Report of the United Nations Conference on Environment and Development, Rio de Janeiro, 3-14 June 1992, Vol.11: Proceedings of the Conference: New York: United Nations.

[45] Wamback, A. E. Constructing an oikotheology: The Environment, Poverty and the Church in South Africa.

[46] Wambutda, D.(1986). An African Christian Looks at Christian Missions in Africa. Readings in Missionary Anthropology 11. California: William Carey Library

[47] Warren, D. M. (1992).Indigenous Knowledge, Biodiversity, Conservation and Development. International Conference on Conservation of Biodiversity in Africa: Local Initiatives and Institutional Roles. Nairobi: Kenya. 
[48] Werner, and Begishe, K. Y. (1980). Ethno science and Applied Anthropology. Indigenous Knowledge Systems and Development. Washington, D.C.: University of America Press.

[49] White, R.(2004). (ed) Controversies in Environmental Sociology. London: Cambridge University Press.
[50] Wolfgram, S. A. (2006).Global Development and Remote African Villages. Environmental Conservation and Cultural Survival in Cameroon.

[51] World commission on Environment and Development(1987). Our Common Future. Oxford: Oxford University Press. 